\section{ANALISIS PENGUNGKAPAN CORPORATE SOCIAL RESPONSIBILITY PERBANKAN SYARIAH INDONESIA BERDASARKAN ISLAMIC SOCIAL REPORTING INDEX}

\author{
Desy Retma Sawitri, Ahmad Juanda, Ahmad Waluya Jati \\ Prodi Akuntansi FEB Universitas Muhammadiyah Malang \\ Jl. Raya Tlogomas No.246 Malang \\ Email:desysari14@gmail.com
}

JRAK

\title{
Abstract
}

The purpose of this research is to evaluate the data shown by Corporate Social Responsibility at shareea banks in Indonesia, which analyzed by ISR index. This research used a sampling method. The samples which are used for the purpose of this research are the purposive sampling taken from shareea banks at Indonesia which already registered on 2015 and 2016. The result of this research showed that Indonesia Muamalat Bank scored the highest at CSR at 86\% and disclosed consistently, while Victoria Bank of Indonesia scored the lowest at 54\%. The data also showed that there were four shareea banks which ranked as very informative, they were: Indonesia Muamalat Bank, Shareea Bank of Indonesia Nation, Mandiri Shareea Bank, and Central Asia Bank. There were also five shareea banks which simply ranked informative, they were: Mega Shareea Bank, Shareea Bank of Indonesia Citizen, Bukopin Shareea Bank, Shareea Bank of Banten of West Java and Panin Shareea Bank. Last, there were two banks which are evaluated as less informative namely Shareea Bank of Maybank Indonesia and Victoria Shareea Bank.

Keywords: Corporate Social Responsibility, ISR index, Shareea Banks

\section{PENDAHULUAN}

Tanggung jawab sosial dan lingkungan, atau lebih sering disebut Corporate Social Responsibility (CSR) semakin menjadi sorotan penting beberapa tahun terakhir karena konsep CSR merupakan inti dari etika bisnis perusahaan. Tujuan utama CSR adalah menjadikan perusahaan bukan hanya pada konsep singglebottom-line (SBL) dalam suatu catatan keuangan perusahaan, tetapi juga konsep tripple-bottom-line (TBL) yang mencangkup aspek keuangan, kehidupan sosial serta lingkungan hidup. Konsep CSR tidak hanya ada di ekonomi konvensioal. Tetapi juga berkembang dalam ekonomi berbasis Islam(Muhammad, 2009).

Indeks ISR merupakan suatu standar pelaporan atas pengungkapan CSR perusahaan-perusahaan yang berbasis syariah. Indeks ini berisi kompilasi itemitem perusahaan pengungkapan CSR yang ditetapkan oleh AAOIFI (Accounting and Auditing Organization for Islamic Financial Institutions) yang kemudian dikembangkan oleh peneliti selanjutnya sehingga item-item tersebut dianggap relevan untuk digunakan oleh entitas syariah. Adapun beberapa penelitian yang telah mengembangkan Indeks ISR diantaranya:(Haniffa et al., 2002) yang menggagas indeks ISR yang kemudian dilanjutkan oleh (Othman et al., 2009). Adapun(Haniffa et al., 2002) membuat lima tema pengungkapan indeks ISR, yaitu Tema Pendanaan dan Investasi, Tema Produk dan Jasa, Tema Karyawan, Tema Masyarakat, dan Tema Lingkungan Hidup. Kemudian dikembangkan oleh Othman et al (2009) dengan menambahkan satu tema pengungkapan yaitu Tema Tata

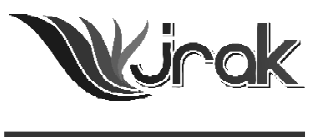

Jurnal Reviu Akuntansi dan Keuangan ISSN: 2088-0685 Vol. 7 No. 1, April 2017 Pp 983-992 
Analisis

Pengungkapan

Corporate

Social...

984
Kelola Perusahaan. Corporate Social Responsibility (CSR) dalam perspektif Islam dalam AAOIFI (2010) yaitu segala kegiatan yang dilakukan institusi keuangan Islam untuk memenuhi kepentingan religius, ekonomi, hukum, etika, dan discretionary responpsibilities. Hal tersebut terkait dengan tanggungjawab religius yang melekat pada bank syariah untuk mematuhi kewajibannya berdasarkan syariat dalam seluruh kegiatan oprasionalnya (junaidi, 2015).

Pengungkapan CSR di Indonesia tidak lagi menggunakan yang bersifat sukarela, melainkan merupakan bagian dari kewajiban perusahaan yang diatur dalam undang-undang No. 40 tahun 2007 tentang perseroan terbatas (UUPT) yang di sahkan pada 20 Juli 2007. Pada pasal 74 undang-undang perseroan terbatas menyatakan: (1) perseroan yang menjalankan kegiatan usahanya di bidang dan/atau berkaitan dengan sumber daya alam wajib melaksanakan tanggungjawab sosial dan lingkungan (TJSL): (2) TJSL merupakan kewajiban perseroan yang dianggarkan dan diperhitungkan sebagai biaya berseroan yang pelaksanaannya dilakukan dengan memperhatikan kepatuhan dan kewajaran; (3) perseroan yang tidak melalukan kewajiban dikenai sanksi sesuai dengan ketentuan peraturan perundang-undangan (Cheng dan Christiawan, 2011). Penelitian yag dilakukan tentang pengungkapan CSR yang diteliti oleh (Fitria dan Hartanti, 2010) pada penelitian tersebut menjelaskan bahwa dari tiga sampel bank syariah yang melakukan praktik pengungkapan CSR, pengungkapan dengan menggunakan index GRI lebih besar dari pada menggunakan index ISR. Tingkat pengungkapan CSR dengan index ISR hanya dapat memenuhi maksimal 50\% dari skor maksimal jika semua item dilakukan secara sempurna.

Mengingat industri perbankan syariah di Indonesia saat ini sedang tumbuh dengan cukup pesat, ditambah dengan isu pengukuran CSR yang makin marak, maka penelitian ini mencoba untuk menelaah bagaimana analisis pengungkapan Corporate Social Responsibility perbankan syariah di Indonesia berdasarkan $I_{S^{-}}$ lamic Social Reporting. Berdasarkan hasil penelitian terdahulu mengenai tanggung jawab sosial Bank Syariah dan Indeks ISR, peneliti tertarik untuk meneliti kembali tingkat pengungkpan CSR Bank Syariah berdasarkan ISR. Adapun kesamaan penelitian ini dengan penelitian terdahulu adalah terletak pada objek penelitian, penggunaan alat ukur Indeks ISR, dan analisis data yang digunakan adalah analisis isi (content analysis). Sedangkan perbedaan terletak pada jumlah item yang diteliti dan periode penelitian. Penelitian ini juga dilengkapi dengan pengukuran indeks, yakni: Sangat Informatif (81\%-100\%), Informatif (66\%-80), Kurang Informatif $(51 \%-66 \%)$ dan tidak informatif $(0 \%-50 \%)$.

\section{LANDASAN TEORI}

\section{Disclosure}

Disclosure merupakan pengungkapan yang berarti tidak menutupi atau tidak menyembunyikan. Jika dikaitkan dengan data, disclosure berarti memberikan data yang bermanfaat kepada pihak yang memerlukan. Apabila dikaitkan dengan informasi berarti disclosure merupakan pengungkapan informasi yang diperlukan bagi seseorang yang membutukan suatu informasi tersebut. Sehingga informasi tersebut harus lengkap, jelas, dan dapat dipertanggung jawabkan. Dalam laporan keuangan, disclosure mengandung arti bahwa laporan keuangan harus memberikan informasi dan pejelasan yang cukup mengenai hasil aktivitas suatu unit usaha. Informasi yang diungkapkan harus berguna dan tidak membingungkan pemakai laporan keuangan dalam membantu pengambilan keputasan ekonomi. (Darrough dan Russell, 2002) mengemukakan dua jenis pengungkapan dalam hubungannya dengan persyaratan yang ditetapkan oleh standar, yaitu pengungkpan wajib (Mandotory Disclosure) dan pengungkapan sukarela (Voluntary Disclosure). 
Pengungkapan tanggung jawab sosial perusahaan yang sering juga disebut social disclosure, corporate social reporting, social accounting (Mathews, 1995) atau corporate social responsibility (Hackston dan Milne, 1996) merupakan proses pengkomunikasian dampak sosial dan lingkungan dari kegiatan ekonomi organisasi terhadap kelompok khusus yang berkepentingan dan terhadap masyarakat secara keseluruhan. (Sembiring dan Rismanda, 2006) Konsep CSR dapat dilihat dari dua sudut pandang yang berbeda. Konsep pertama menyatakan bahwa tujuan perusahaan adalah mencari laba, sehingga CSR merupakan sebuah strategi dalam operasi bisnis.

\section{Pengungkapan Corporate Social Responsibility}

(Cheng dan Christiawan, 2011) didalam jurnalnya menurut Word Business Council for Sustainable Development menjelaskan CSR merupakan suatu komitmen berkelanjutan oleh dunia usaha untuk bertindak secara etis dan memberikan kontibusi kepada pengembangan ekonomi dari komunitas setempat maupun masyarakat secara luas, bersamaan dengan peningkatan taraf hidup pekerjaannya beserta seluruh keluarganya. Pelaksanaan tanggungjawab sosial perusahaan memiliki manfaat bagi perusahaan, masyarakat, lingkungan, negara, dan para memangku kepentingan lainnya (Fauziah dan J, 2013).

\section{Konsep Corporate Social Responsibility Dalam Islam}

Islam sebagai cara hidup memberikan panduan bagi umatnya untuk beradaptasi dan berkembang sesuai dengan jamannya. Islam memungkinkan umatnya untuk berenovasi dalam muamalah, namun tidak dalam akidah, ibadah dan akhalaq (Kamali dan Hashim, 1997) Lembaga yang menjalankan bisnisnya berdasarkan syariah pada hakekatnya mendasarkan pada filosofi dasar Al Qur'an dan Sunah (Ahmad et al., 2002).

\section{Islamic Social Reporting}

Islamic Social Reporting Index merupakan sebuah standar alternatif yang digunakan untuk mengatur pelaporan tanggungjawab sosial perusahaan yang berbasis syariah. Islamic Social Reporting Index merupakan standar yang dikeluarkan oleh AAOIFI (Accounting and Auditing Organization for Islamic Financial Institution). Index ISR merupakan dari Social Reporting yang meliputi harapan masyarakat tidak hanya mengenai peran perusahaan dalam perekonomian, tetapi juga peran perusahaan dalam perspektif spiritual.

Untuk menentukan index ISR yaitu dengan content analisis pada laporan tahunan perusahaan dengan memberikan tanda checklist pada setiap item yang mengungkapkan tanggung jawab sosial. Jika terdapat satu item yang diungkapkan maka akan mendapat skor "1", dan jika tidak maka mendapatakan skor "0". 
Analisis

Pengungkapan

Corporate

Social...

986
Gambar 1.1 kerangka pemikiran

\section{Kerangka Pemikiran}

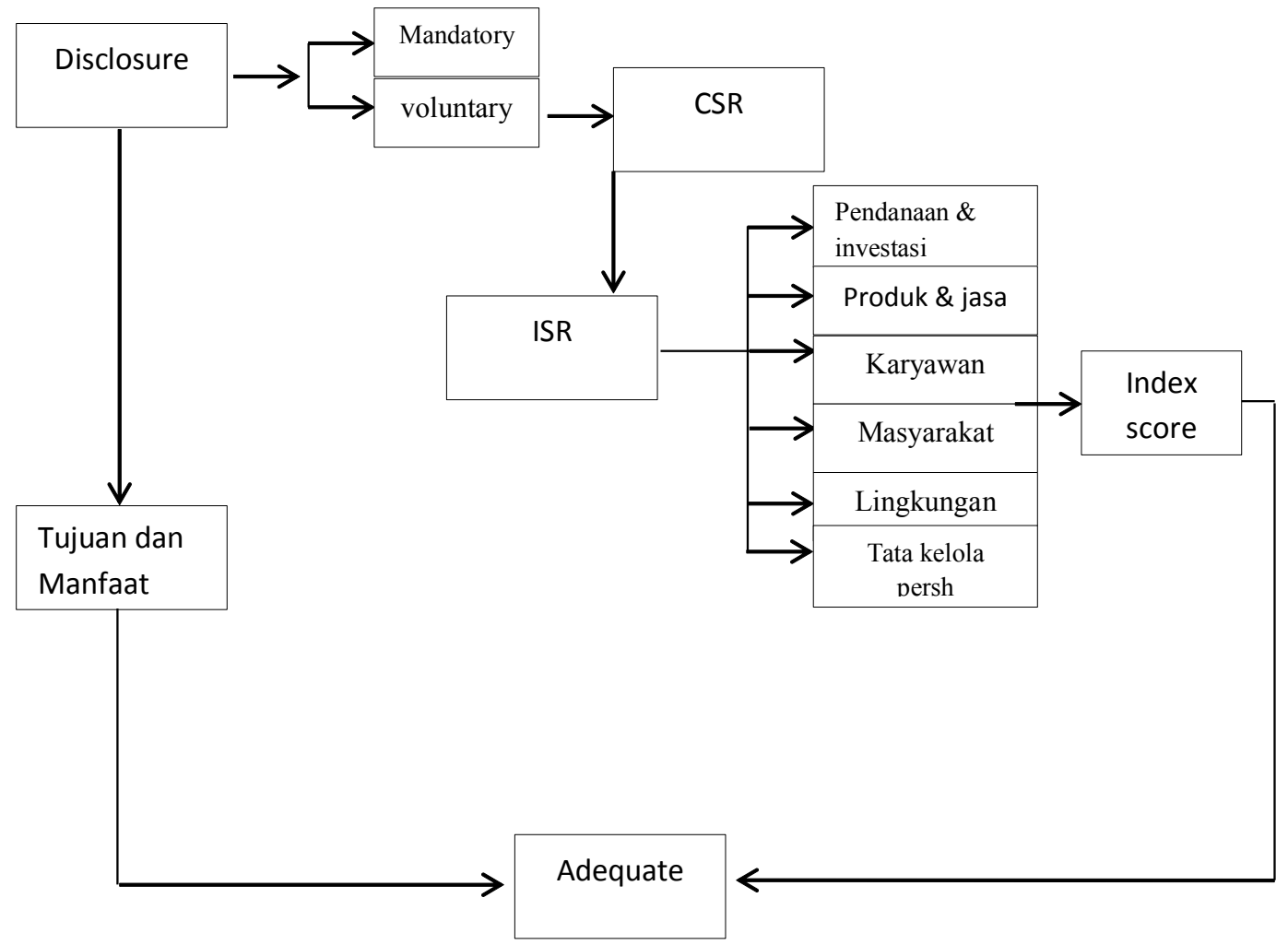

\section{METODE}

penelitian yang digunakan pada penelitian ini adalah deskriptif dengan Pengambilan sampel dilakukan dengan menggunakan metode purposive sampling Adapun kriteria yang menjadi dasar pemilihan sampel berdasarkan tujuan penelitian adalah:

1. Bank Umum Syariah yang terdaftar di Bank Indonesia pada tahun 20152016

2. Bank Umum Syariah yang mempublikasikan laporan tahunan dan laporan keuangan dari tahun 2015-2016.

Data yang digunakan pada penelitian ini yaitu data Bank Umum Syariah dan lapotan tahunan (annual Report) perbankan syariah yang diperoleh dari situs Bank Indonesia (BI) atau di situs web resmi dari perbankan syariah itu sendiri. Adapun langkah-langkah untuk menunjang analisis isi tersebut adalah sebagai berikut:

1. Langkah pertama yaitu mengidentifikasi dan mengklasifikasikan berbagai informasi yang terdapat dalam laporan tahunan Bank Umum Syariah di indonesia sesuai dengan item-item ISR yang digunakan.

2. Melakukan penilaian (scoring) indeks ISR pada Bank Umum Syariah. Scoring dilakukan untuk mencari poin pengungkapan yang dinilai dengan 1 jika terdapat sub-tema yang diungkapkan dan 0 jika terdapat sub-tema yang tidak diungkapkan dari item pengungkapan yang telah dijabarkan dalam tabel.

3. Selanjutnya akan dilakukan analisis konten terhadap tiap-tiap tema indeks ISR pada setiap Bank Umum Syariah untuk mengetahui tingkat pengungkapan CSR Bank Syariah. Selanjutnya dilakukan penilaian secara kumulatif indeks ISR pada Bank Umum Syariah (BUS) yang akan menentukan tingkat pengungkapan CSR Bank Umum Syariah (BUS). 
4. Untuk memudahkan dalam mengetahui seberapa besar tingkat pengungkapan CSR di Bank Umum Syariah akan digunakan pendekatan pada (Zanariyatim dan Sahroni, 2016) maka dilakukan Rumus sebagai berikut:

Indeks ISR $=\frac{\text { jumla } h \text { item yang diungkapkan ole } h \text { perusa haan } X 100 \%}{\text { jumla } h \text { item maksimal }}$

5. menentukan predikat tingkat pengungkapan CSR dari masing-masing BUS. Dalam penilaian tingkat pengungkapan kinerja sosial BUS, akan digunakan pendekatan yang mengacu pada Munawaroh (2007) dalam (Gustani et al., 2017) dimana skor pengungkapan diklasifikasikan dalam 4 kategori: Sangat Informatif (81-100), Informatif (66-80), Kurang Informatif (51-66) dan tidak informatif (0-50).

\begin{tabular}{ll}
\hline Predikat & Nilai Indeks \\
Sangant Informatif & $81 \%-100 \%$ \\
Informatif & $66 \%-80 \%$ \\
Kurang Informatif & $51 \%-66 \%$ \\
Tidak Informatif & $0 \%-50 \%$ \\
\hline
\end{tabular}

Tabel 1

Predikat tingkat pengungkapan CSR Bank Syariah

berdasarkan Indeks ISR

6. selanjutnya menganalisis dan mengidentifkasi aspek Islamic Social Reporting yang sudah dan belum diungkapkan.

\section{HASIL DAN PEMBAHASAN}

\begin{tabular}{|c|c|c|c|c|c|}
\hline \multirow{2}{*}{ No } & \multirow{2}{*}{ Nama Perusahaan } & \multicolumn{4}{|c|}{ Tahun \& Predikat } \\
\hline & & 2015 & Predikat & 2016 & Predikat \\
\hline 1 & $\begin{array}{l}\text { PT BANK MUAMALAT } \\
\text { INDONESIA }\end{array}$ & $86 \%$ & $\begin{array}{l}\text { sangat } \\
\text { informatif }\end{array}$ & $86 \%$ & $\begin{array}{l}\text { sangat } \\
\text { informatif }\end{array}$ \\
\hline 2 & $\begin{array}{l}\text { PT BANK SYARIAH } \\
\text { MANDIRI }\end{array}$ & $82 \%$ & $\begin{array}{l}\text { sangat } \\
\text { informatif }\end{array}$ & $82 \%$ & $\begin{array}{l}\text { sangat } \\
\text { informatif }\end{array}$ \\
\hline 3 & $\begin{array}{l}\text { PT BANK MEGA } \\
\text { SYARIAH }\end{array}$ & $76 \%$ & Informatif & $76 \%$ & Informatif \\
\hline 4 & PT BANK BRI SYARIAH & $78 \%$ & Informatif & $78 \%$ & Informatif \\
\hline 5 & $\begin{array}{l}\text { PT BANK SYARIAH } \\
\text { BUKOPIN }\end{array}$ & $80 \%$ & Informatif & $80 \%$ & Informatif \\
\hline 6 & PT BANK BNI SYARIAH & $82 \%$ & $\begin{array}{l}\text { sangat } \\
\text { informatif }\end{array}$ & $84 \%$ & $\begin{array}{l}\text { sangat } \\
\text { informatif }\end{array}$ \\
\hline 7 & $\begin{array}{l}\text { PT BANK JABAR } \\
\text { BANTEN SYARIAH }\end{array}$ & $80 \%$ & informatif & $80 \%$ & Informatif \\
\hline 8 & PT BCA SYARIAH & $82 \%$ & $\begin{array}{l}\text { sangat } \\
\text { informatif }\end{array}$ & $82 \%$ & $\begin{array}{l}\text { sangat } \\
\text { informatif }\end{array}$ \\
\hline 9 & $\begin{array}{l}\text { PT BANK VICTORIA } \\
\text { SYARIAH }\end{array}$ & $54 \%$ & $\begin{array}{l}\text { kurang } \\
\text { informatif }\end{array}$ & $54 \%$ & $\begin{array}{l}\text { kurang } \\
\text { informatif }\end{array}$ \\
\hline 10 & $\begin{array}{l}\text { PT BANK PANIN } \\
\text { SYARIAH }\end{array}$ & $80 \%$ & informatif & $80 \%$ & Informatif \\
\hline 11 & $\begin{array}{l}\text { PT MAYBANK SYARIAH } \\
\text { INDONESIA }\end{array}$ & $62 \%$ & $\begin{array}{l}\text { kurang } \\
\text { informatif }\end{array}$ & $70 \%$ & Informatif \\
\hline
\end{tabular}

Tabel 2

Tinggat Predikat Pengungkapan BUS Pada Tahun 2015-2016

Berdasarkan hasil analisis isi pada tabel 2 menunjukan bahwa angka tertinggi diraih oleh Bank Muamalat Indonesia dengan skor yang diraih mencapai 86\% dari tahun 2015 hingga 2016. Serta pada Bank Syariah Mandiri, Bank Syariah Bukopin, Bank Negara Indonesia Syariah, Bank Central Asia Syariah pada tahun 2015 mendapatkan skor 82\% dengan 41 item dan Bank Syariah tersebut menda- 


\section{Analisis \\ Pengungkapan \\ Corporate \\ Social...}

988

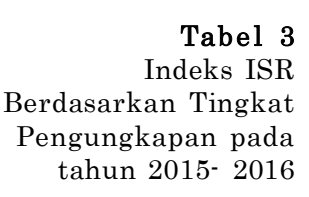

tahun 2015- 2016 patkan predikat Sangat Informatif. Bank Rakyat Indonesia Syariah, Bank Jabar Banten Syariah, dan Bank Panin Syariah mengalami perolehan skor yang konsisten pada tahun 2015-2016 dengan predikat Informatif dengan skor yang diraih $80 \%$ dengan pengungkapan sebanyak 40 item. Kemudian Bank Mega Syariah pada tahun 2015 hingga 2016 mendapatkan skor 78\% dengan pengungkapan sebanyak 39 item sedangkan Maybank Syariah pada tahun 2015 mendapatkan skor $62 \%$ dengan 31 item yang diungkapkan serta meningkat pada tahun 2016 menjadi $70 \%$ dengan pengungkapan sebanyak 35 item dengan predikat Informatif pada tahun tersebut. Bank syariah yang mendapatkan predikat Kurang informatif secara konsisten pada tahun 2015-2016 yaitu Bank Victoria Syariah dengan skor yang didapat 54\% dengan 27 item pengungkapan CSR yang dilakukan oleh Bank Syariah tersebut.

\begin{tabular}{clcc}
\hline No. & \multicolumn{1}{c}{ Tema Pengungkapan } & $\mathbf{2 0 1 5}$ & $\mathbf{2 0 1 6}$ \\
\hline 1 & Tata Kelola Perusahaan & $100 \%$ & $100 \%$ \\
2 & Karyawan & $80 \%$ & $82 \%$ \\
3 & Masyarakat & $73 \%$ & $77 \%$ \\
4 & Produk dan Jasa & $75 \%$ & $75 \%$ \\
5 & Pendanaan dan Investasi & $67 \%$ & $67 \%$ \\
6 & Lingkungan hidup & $38 \%$ & $38 \%$ \\
\hline
\end{tabular}

Tabel 3 menunjukan bahwa pengungkapan tentang aspek tema dalam Indeks ISR pada Bank Umum Syariah tahun 2015-2016 yaitu tema Tata Kelola Perusahaan dengan jumlah penilaian 100\% yang diungkapkan oleh perbankan Syariah sedangkan pengungkapan yang terendah yaitu tema lingkungan hidup dengan jumlah penilaian 38\% dengan sangan kurang diungkapkan oleh Bank Umum Syariah di Indonesia.

Hasil dari pengungkapan CSR berdasarkan indeks ISR pada Bank Umum Syariah terus mengalami peningkatan pada setiap tahunnya. Pada tahun 2015 Bank Umum Syariah yang dianggap telah baik dalam pengungkapan CSR berdasarkan Indeks ISR sebanyak 4 (empat) Bank Syariah yaitu, Bank Muamalat Indonesia, Bank Syariah Mandiri, Bank Negara Indonesia dan Bank Central Asia Syariah. Dengan memperoleh predikat Sangat Informatif. Sedangakan pada tahun 2016 mendapatkan hasil yang sama dengan tahun yang sebelumnya yaitu, terdapat 4 (empat) Bank Syariah yang dianggap sudah baik dalam pengungkapan CSR berdasarkan indeks ISR.

Pengungkapan Indeks ISR pada Bank Umum Syariah di Indonesia sudah seharusnya pada Bank Syariah Indonesia dalam melaporkan CSR nya dengan menggunakan alat ukur Indeks ISR bahwa pengungkapan secara konsisten sembilan Bank Syariah yang Mengungkapkan CSR berdasarkan Indeks ISR dengan baik dari sebelas Bank Syariah Yang menjadi Sampel pada penelitian ini. Sedangkan 2 Bank syariah yang masih kurang dalam pengungkapan CSR berdasarkan Indeks ISR.

Pengungkapan Indeks ISR dengan kegiatan pendanaan dan investasi seluruh Bank Syariah tidak ada yang mengungkapkan tentang grahar dan pengungkapan kebijakan tentang penundaan atau penjadwalan ulang pembayaran jika kreditor mengalami kesulitan melainkan hanya mengungkapkan seluruh dana denda keterlambatan diakui sebagai dana Kebajikan. Maka munculah masalah dan pernyataan kenapa dana non halal tetap dipungut oleh Bank Syariah dan dianggap merugikan kreditor ini tentunya tidak sesuai dengan syariat islam.

Adapun dampak yang diperoleh Bank Umum Syariah dalam mengungkapkan CSR bendasarkan Indeks ISR sebagai alat ukur dalam pelaporan CSR nya adalah sebagai berikut: 
1. Dapat menunjukan kepada masyarakat mengenai peran perusahaan dalam perspektif spiritual, sehingga masyarakat tidak hanya mengetahui tentang peran perusahaan terhadap prekonoemian nya saja, akan tetapi lebih luas dari pada itu dengan kegiatan yang sosial, karyawan, lingkungan, dan tata kelola perusahaan dengan berdasarkan nilai-nilai islami didalamnya.

2. Dapat memberikan feedback yang baik bagi Bank Umum Syariah dalam peningkatan penjualan Produk, dimana pada dasarnya Indeks ISR sangat memperhatikan kehalalan atas produk yang dihasilkan. Selanjutnya dampak positif yang yang diperoleh perusahaan yang menerapkan Indeks ISR dalam kesejahteraan karyawannya akan lebih sejahtera sehingga mendapatkan perlindungan yang lebih karena Indeks ISR sangat memperhatikan sikap dan perilaku terhadap karyawan lebih luas seperti tersedianya tempat ibadah yang memadai.

3. mempererat hubungan antara perusahan dengan stakeholder Hal ini dikarenakan stakeholder merasa yakin dan percaya atas dana yang diinvestasikan ke perusahaan akan aman. Indeks ISR memperhatikan aktivitas yang mengandung riba dan grahar. Sehingga perusahaan dapat terhindar dari aktivitas yang terlarang.

\section{Pembahasan}

Hasil dari pengungkapan CSR berdasarkan indeks ISR pada Bank Umum Syariah terus mengalami peningkatan pada setiap tahunnya. Pada tahun 2015 Bank Umum Syariah yang dianggap telah baik dalam pengungkapan CSR berdasarkan Indeks ISR sebanyak 4 (empat) Bank Syariah yaitu, Bank Muamalat Indonesia, Bank Syariah Mandiri, Bank Negara Indonesia dan Bank Central Asia Syariah. Dengan memperoleh predikat Sangat Informatif. Sedangakan pada tahun 2016 mendapatkan hasil yang sama dengan tahun yang sebelumnya yaitu, terdapat 4 (empat) Bank Syariah yang dianggap sudah baik dalam pengungkapan CSR berdasarkan indeks ISR.

Hasil dari penelitian ini memberikan hasil konfirmasi terhadap penelitian (Khoirudin, 2013) bahwa ukuran dewan komisaris terbukti memiliki positif signifikan terhadap pengungkapan Islamic Social Responsibility pada perbankan syariah di Indonesia. Kemudian mengkonfirmasi pula hasil temuan (Haniffa et al., 2007) bahwa pada hasil penelitian ini tidak sejalan dengan penelitian yang dilakukan yang menyatakan bahwa keseluruhan rata-rata indeks identitas etis terdapat satu bank syariah yang mendapatkan nilai diatas rata-rata dari tujuh bank syariah yang di teliti. Akan tetapi penelitian ini konsisten dalam hasil penelitian pada tahun 2015-2016 dimana empat bank syariah yang mendapatkan skor tertinggi dengan predikat Sangat Informatif dan lima bank syariah mendapatkan nilai diatas standar dengan mendapatkan predikat Informatif, sedangkan yang kurang mengungkapkan CSR nya dengan Indeks ISR dengan nilai yang dibawah standar yaitu 2 Bank Syariah dan mendapatkan predikat Kurang Informatif.

Pengungkapan Indeks ISR pada Bank Umum Syariah di Indonesia sudah seharusnya pada Bank Syariah Indonesia dalam melaporkan CSR nya dengan menggunakan alat ukur Indeks ISR bahwa pengungkapan secara konsisten sembilan Bank Syariah yang Mengungkapkan CSR berdasarkan Indeks ISR dengan baik dari sebelas Bank Syariah Yang menjadi Sampel pada penelitian ini. Sedangkan 2 Bank syariah yang masih kurang dalam pengungkapan CSR berdasarkan Indeks ISR.

Pengungkapan Indeks ISR dengan kegiatan pendanaan dan investasi seluruh Bank Syariah tidak ada yang mengungkapkan tentang grahar dan pengungkapan kebijakan tentang penundaan atau penjadwalan ulang pembayaran jika 
Analisis

Pengungkapan

Corporate

Social...

990 kreditor mengalami kesulitan melainkan hanya mengungkapkan seluruh dana denda keterlambatan diakui sebagai dana Kebajikan. Maka munculah masalah dan pernyataan kenapa dana non halal tetap dipungut oleh Bank Syariah dan dianggap merugikan kreditor ini tentunya tidak sesuai dengan syariat islam.

Adapun dampak yang diperoleh Bank Umum Syariah dalam mengungkapkan CSR bendasarkan Indeks ISR sebagai alat ukur dalam pelaporan CSR nya adalah sebagai berikut:

1. Dapat menunjukan kepada masyarakat mengenai peran perusahaan dalam perspektif spiritual, sehingga masyarakat tidak hanya mengetahui tentang peran perusahaan terhadap prekonoemian nya saja, akan tetapi lebih luas dari pada itu dengan kegiatan yang sosial, karyawan, lingkungan, dan tata kelola perusahaan dengan berdasarkan nilai-nilai islami didalamnya.

2. Dapat memberikan feedback yang baik bagi Bank Umum Syariah dalam peningkatan penjualan Produk, dimana pada dasarnya Indeks ISR sangat memperhatikan kehalalan atas produk yang dihasilkan. Selanjutnya dampak positif yang yang diperoleh perusahaan yang menerapkan Indeks ISR dalam kesejahteraan karyawannya akan lebih sejahtera sehingga mendapatkan perlindungan yang lebih karena Indeks ISR sangat memperhatikan sikap dan perilaku terhadap karyawan lebih luas seperti tersedianya tempat ibadah yang memadai.

3. mempererat hubungan antara perusahan dengan stakeholder Hal ini dikarenakan stakeholder merasa yakin dan percaya atas dana yang diinvestasikan ke perusahaan akan aman. Indeks ISR memperhatikan aktivitas yang mengandung riba dan grahar. Sehingga perusahaan dapat terhindar dari aktivitas yang terlarang.

\section{Simpulan}

Berdasarkan hasil skoring Islamic Social Reporting Indeks(Indeks ISR) dalam pengungkapan Corporate Social Responsibility (CSR) perbankan syariah Indonesia, maka dapat disimpulkan bahwa pengungkapan Indeks ISR pada 11 bank syariah hanya 9 bank syariah dikatakan baik, yakni sebasar 77\% secara keseluruhan, walaupun masih belum mencapai angka sempurna 100\%, dikarenakan masih adanya item-item Indeks ISR yang belum diungkapkan secara penuh. hal ini mengidentifikasi transparasi dalam pengungkapan sehubungan dengan nilainilai Islam.

Berdasarkan pengungkapan dalam aspek pendanaan dan investasi, kemasyarakatan serta tata kelola perusahaan merupakan paling banyak diungkapkan. Hal ini menandakan sudah semakin tumbuhnya kesadaran bank syariah mengenai tanggungjawab sosial dan status syariah (halal) produk dan jasanya serta memenuhi unsur kepatuhan, sehingga diungkapkan sangat baik oleh sebelas bank syariah yang menjadi sampel pada penelitian.

Penelitian ini dimulai dengan menggunkan analisis isi (content analysis) subjektifitas peneliti dalam membaca, memahami, dan melakukan checklist skor atas laporan tahunan perbankan syariah untuk mengidentifikasi dalam pengungkapan Corporate Social Responsibility dengan menggunakan alat ukur Indeks ISR menjadi tidak terelakan. Teknik perolehan data pada penelitian ini hanya dengan cara dokumetasi yaitu melihat data laporan tahunan perusahaan. Hal ini dapat memungkinkan hasil analisis data tidak maksimal. 
Ahmad, Q., R. Allen, T. Andersen, J. Anglin, J. Barton, E. Beier, M. Bercovitch, J. Bigu, S. Biller, dan R. Black. 2002. "Direct Evidence For Neutrino Flavor Trans" formation From Neutral-Current Interactions In The Sudbury Neutrino Observatory". Physical review letters, Vol. 89, No. 1, hlm: 011301.

Cheng, M., dan Y. J. Christiawan. 2011. "Pengaruh Pengungkapan Corporate Social Responsibility Terhadap Abnormal Return”. Jurnal Akuntansi Dan Keuangan, Vol. 13, No. 1, hlm: 12.

Darrough, M. N., dan T. Russell. 2002. "A positive model of earnings forecasts: Top down versus bottom up". The Journal of Business, Vol. 75, No. 1, hlm: 127152.

Fauziah, k., dan P. Y. J. 2013. "Analisis pengungkapan Tanggung Jawab Sosial Perbankan Syariah Di Indonesia Berdasarkan Islamic Social Reporting". Jurnal Dinamika Akuntansi, Vol. 5, No. 1, hlm: 20.

Fitria, S., dan D. Hartanti. 2010. "Islam dan Tanggung Jawab Sosial: Studi Perbandingan Pengungkapan Berdasarkan Global Reporting Initiative Indek dan Islamic Social Reporting Indeks". Simposium Nasional Akuntansi XIII purwokerto, Vol., No., hlm.

Gustani, Gustani, Bayinah, dan A. Nur. 2017. "Model Pelaporan Kinerja Sosial Perbankan Syariah: Implementasi Islamic Social Reporting Index (Indek ISR) Di Indonesia”. Jurnal Akuntansi dan Keuangan Islam, Vol. 2, No. 1, hlm.

Haniffa, Roszaini, Hudaib, dan Mohammad. 2007. "Exploring The Ethical Identity Of Islamic Banks Via Communication In Annual Reports". Journal of Business Ethics, Vol. 76, No. 1, hlm: 97-116.

Haniffa, R., Hudaib, dan M. Abdullah. 2002. "A theoretical framework for the development of the Islamic perspective of accounting". Accounting, Commerce and Finance: The Islamic Perspective Journal, Vol. 6, No. 1/2, hlm: 1-71.

junaidi. 2015. "Analisis Pengungkapan CSR Perbankan Syariah di Indonesia Berdasarkan Islamic Social Reporting Index". jurnal Akuntansi \& Investasi, Vol. 16, No. 01, hlm: 13.

Kamali, dan M. Hashim. 1997. Freedom Of Expression In Islam: Islamic Texts Society Cambridge.

Khoirudin, A. 2013. "Corporate Governance Dan Pengungkapan Islamic Social Reporting Pada Perbankan Syariah di Indonesia". Accounting Analysis Journal, Vol. 2, No. 2, hlm.

Muhammad, R. 2009. "Studi Evaluasi Terhadap Perbankan Syariah Di Indonesia”. Jurnal Akuntansi \& Auditng Indonesia, Vol. 13, No. 2, hlm: 20.

Othman, R., A. M. Thani, dan E. K. Ghani. 2009. "Determinan of Islamic SocialReporting AmongTop Syariah-Approved Companies in Bursa Malaysia". Research Jurnal of International Studies, Vol., No. 12, hlm.

Sembiring, dan E. Rismanda. 2006. "Karakteristik Perusahaan Dan Pengungkapan Tanggung Jawab Sosial: Study Empiris Pada Perusahaan Yang Tercatat Di Bursa Efek Jakarta”. MAKSI, Vol. 6, No., hlm.

Zanariyatim, A., dan A. N. B. d. O. Sahroni. 2016. "PENGUNGKAPAN CORPORATE SOCIAL RESPONSIBILITY (CSR) BANK UMUM SYARIAH BERDASARKAN ISLAMIC SOCIAL REPORTING INDEX (INDEKS ISR)”. Jurnal Akuntansi dan Keuangan Islam, Vol. 4, No. 1, hlm. 
